\title{
Antioxidant Activity and Metabolomic Analysis of Cagaitas (Eugenia dysenterica) Using Paper Spray Mass Spectrometry
}

\author{
Mauro R. Silva, ${ }^{a}$ Lucas G. Freitas, ${ }^{a}$ Amauri G. Souza, ${ }^{b}$ Raquel L. B. Araújo, ${ }^{a}$ \\ Inayara C. A. Lacerda, ${ }^{a}$ Hebert V. Pereira, ${ }^{c}$ Rodinei Augusti ${ }^{\oplus c}$ and Júlio O. F. Melo ${ }^{\circledR * b}$ \\ ${ }^{a}$ Departamento de Alimentos, Universidade Federal de Minas Gerais (UFMG), \\ 31270-901 Belo Horizonte-MG, Brazil \\ ${ }^{b}$ Departamento de Ciências Exatas e Biológicas, Universidade Federal de São João Del-Rei \\ (UFSJ), 35701-970 Sete Lagoas-MG, Brazil \\ 'Departamento de Química, Universidade Federal de Minas Gerais (UFMG), \\ 31270-901 Belo Horizonte-MG, Brazil
}

\begin{abstract}
Cagaita is a fruit from Brazilian cerrado, belongs to Myrtaceae family, and has important economic value. This work aimed to determine the total antioxidant capacity (extractable and nonextractable fractions) by different methods and to evaluate the use of paper spray mass spectrometry to obtain fingerprints of cagaita from different regions with the aid of principal components analysis. Cagaitas had higher antioxidant activity than those found in other fruits mentioned in literature, and the non-extractable fraction was 18.90 to $21.05 \%$ of the antioxidant capacity. The analysis of paper spray mass spectrometry in positive and negative ionization modes identified several substances, including organic acids, sugars, amino acids and several other classes of phenolic compounds. Analysis of the main components of cagaita samples permitted discrimination of the major constituents such as sugars and different kinds of phenolic compounds. Thus, this study demonstrated that paper spray mass spectrometry is a simple and ultrafast method with minimum sample preparation that allows the analysis of the chemical profile of cagaita.
\end{abstract}

Keywords: paper spray, principal components analysis, ABTS, FRAP, DPPH

\section{Introduction}

Cerrado, also known as Brazilian Savanna, is a South American biome of around 200 million hectares and covers about $22 \%$ of Brazil's territory. It is recognized for its biodiversity of fauna and flora, as well as the abundance of natural resources. For the sustainable exploitation of these resources, the native species of this region need to be characterized. ${ }^{1,2}$ A typical specie of this biome is cagaiteira (Eugenia dysenterica), an angiosperm belonging to Myrtaceae family. Its fruit, called cagaita, is widely used by local residents. ${ }^{1,3,4}$

Scientific studies report that this fruit is a source of bioactive substances with antioxidant activity, which have been associated with prevention of diseases such as cancer, cardiovascular and cerebrovascular diseases. The antioxidant activity of foods needs to be determined with

*e-mail: onesiomelo@gmail.com different methods that use other mechanisms to reliably quantify foods with a complex matrix. Among the most used methods are the 2,2-diphenyl-1-picrylhydrazil (DPPH), ferric reducing antioxidant power (FRAP) and 2,20-azino-bis(3-ethylbenzthiazoline-6-sulfonic acid) (ABTS). ${ }^{5}$

Studies about the components of cagaitas have focused on determining extractable phenolic compounds, in other words, components isolated in solution from solid-liquid extraction of fruit pulp. However, significant levels of these substances remain present in the sample, which can lead to hasty conclusions. Therefore, it is important to quantify both the extractable and non-extractable polyphenols. ${ }^{6}$

For broader characterization of cagaita, instrumental analytical techniques can be used, such as, high performance liquid chromatography (HPLC) with UV detection and/or mass spectrometry, capillary electrophoresis and gas chromatography mass spectrometry. In general, they provide accurate and precise qualitative and quantitative 
analyses, despite disadvantages as requiring laborious sample preparation, extensive time and expense. Recent developments in mass spectrometry techniques with direct analysis have overcome such limitations and provide ultrafast analyses of complex matrices at low cost. They minimize or eliminate sample preparation and promote ionization of analytes under gentle experimental conditions. ${ }^{7,8}$

Among the ambient ionization techniques, several methods have been developed from electrospray ionization (ESI) such as desorption electrospray ionization mass spectrometry (DESI-MS), paper spray and electrospray assisted laser desorption/ionization (ELDI). Paper spray mass spectrometry (PS-MS), developed by Wang et al., 9 has been widely used to analyze substances in complex matrices. A great advantage of PS-MS is the possibility of rapidly obtaining fingerprints in wide ranges of masses. Thus, the PS-MS has been used in studies involving resveratrol in red wine, ${ }^{10}$ olive oil analysis, ${ }^{11}$ chemical composition of whisky and beer fraud verification, ${ }^{12,13}$ coffee classification, ${ }^{14}$ caffeine analysis in commercial beverages $^{15,16}$ and medicines, pesticide analysis in fruits and vegetables, ${ }^{17}$ quality control of tea, ${ }^{18}$ Corni fructus, ${ }^{8}$ dyes, ${ }^{19}$ and food additives and their byproducts. ${ }^{20}$ Other ambient ionization techniques, such as desorption electrospray ionization (DESI), ${ }^{21-24}$ direct analysis in real time (DART), ${ }^{21,23,24}$ easy ambient sonic spray ionization $(\text { EASI })^{21,23}$ and liquid extraction surface analysis (LESA) ${ }^{24}$ have been also successfully explored for fingerprint.

The present study aimed to determine the total antioxidant activity of cagaitas (extractable and nonextractable fraction) using DPPH, ABTS and FRAP methods. We also identified other chemical constituents using PS-MS. In addition, fingerprints of cagaitas collected in three distinct regions were differentiated with aid of principal components analysis (PCA).

\section{Experimental}

\section{Cagaita sample and material}

During the 2016 harvest, ripe fruit were collected separately from 27 matrices of cagaiteira in different places within three microregions of Minas Gerais State (Brazil): Paraopeba (latitude 19 $16^{\prime} 23^{\prime \prime}$ and longitude

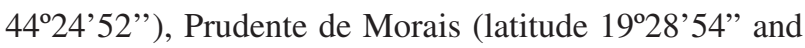

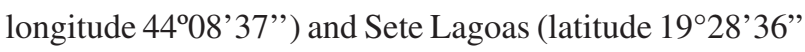
and longitude $\left.44^{\circ} 11^{\prime} 43^{\prime \prime}\right)$. Samples were transported to the Research Laboratory-Food Chemistry Unit of the Federal University of Minas Gerais.

Then, ripe fruit were washed in running water and sanitized using a solution of $200 \mathrm{~m} \mathrm{~L}^{-1}$ sodium hypochlorite for $15 \mathrm{~min}$ followed by running water rinse. Later, samples were stored in a freezer at $-18{ }^{\circ} \mathrm{C}$. Before each analysis, the fruit pulp was obtained by thawing 3 fruit from each sample, seeds discarded and homogenized using a mixer.

The physical-chemical properties and antioxidant activity were determined from a pool made of 3 fruits from 9 cagaiteiras from each microregion. The analysis by PS-MS considered the crude analysis of fruit pulps from 9 cagaiteiras from each of the 3 microregions (27 samples).

All the standards for Folin \& Ciocalteu's phenol reagent, 2,2-di-phenyl-1-picrylhydrazil (DPPH'), 2,20-azinobis(3-ethylbenzthiazoline-6-sulfonic acid) (ABTS'), 2,4,6-tris(2-pyridyl)-s-triazine (TPTZ) and 6-hydroxy2,5,7,8-tetramethylchroman-2-carboxylic acid (trolox) were acquired from Sigma-Aldrich (São Paulo, SP, Brazil). Methanol HPLC grade was acquired from J. T. Baker (Phillipsburg, NJ, USA) and chromatography paper 1 CHR from Whatman (Little Chalfont, Buckinghamshire, UK).

\section{Physical-chemical analyses}

Titratable acidity, $\mathrm{pH}$, soluble solids ( $\left.{ }^{\circ} \mathrm{Brix}\right)$, moisture, protein and ashes were determined, in triplicate, following the methods described by the Association of Official Analytical Chemists (AOAC) ${ }^{25}$ Lipids were analyzed according to the Bligh and Dyer ${ }^{26}$ extraction method, using methanol, chloroform and water. Carbohydrate content was calculated by the difference between 100 and the sum of percentages of moisture, protein, lipids and ashes. The calculation of energy content was performed using conversion factors of $4 \mathrm{kcal} \mathrm{g}^{-1}$ of protein and carbohydrate and $9 \mathrm{kcal} \mathrm{g}^{-1}$ of lipids. ${ }^{27}$

\section{Samples treatment}

\section{Extractable polyphenols}

Extraction was done according to the procedure described by Rufino et al. ${ }^{5}$ For this, $0.5 \mathrm{~g}$ of sample and $1 \mathrm{~mL}$ of methanol/water $(50: 50, \mathrm{v} / \mathrm{v})$ were added inside a $2 \mathrm{~mL}$ Eppendorf tube. After $1 \mathrm{~h}$ at room temperature, the tubes were centrifuged at $25,406 \times \mathrm{g}$ for $15 \mathrm{~min}$ and the supernatant retrieved. Afterward, $1.0 \mathrm{~mL}$ of acetone/ water $(70: 30, \mathrm{v} / \mathrm{v})$ was added to the residue, with a new incubation and centrifuging at the same conditions above. Both supernatants were mixed, and distilled water added until $5.0 \mathrm{~mL}$ was reached.

\section{Hydrolysable polyphenols and non-extractable proanthocyanidin}

The hydrolysable polyphenols and the non-extractable proanthocyanidin were obtained according to the methods described by Hartzfeld et al. ${ }^{28}$ and Arranz et al. ${ }^{29}$ 
Total phenolic compounds and antioxidant activity

The obtained extracts were used to determine the content of phenolic compounds and to evaluate the antioxidant activity. Thus, the phenolic compounds of cagaita were determined following the procedure of Singleton et al. ${ }^{30}$ The antioxidant activity was evaluated by FRAP, ABTS and DPPH methods; the first two were carried out according to Rufino et al. ${ }^{5}$ and the last one according to the $\mathrm{AOAC}^{25}$ protocol.

\section{PS-MS fingerprints}

The chemical profile analysis of the samples was done using a mass spectrometer LCQ Fleet (Thermo Scientific, San Jose, CA, USA) equipped with a paper spray ionization source. The 27 samples were analyzed in positive and negative ionization modes.

Figure 1 is the diagram of the ionization source for paper spray. To carry out the analyses, chromatographic paper was cut in an equilateral triangle shape $(1.5 \mathrm{~cm})$ and positioned in front of the mass spectrometer entrance. This paper was supported by a metal connector and positioned $0.5 \mathrm{~cm}$ away with the aid of a movable platform (XYZ). This apparatus was connected to a high-voltage source of the spectrometer through a copper wire. Ultimately, $2.0 \mu \mathrm{L}$ of pulp was applied on the edge of the triangles, $40.0 \mu \mathrm{L}$ of methanol was transferred to the chromatographic paper and the voltage source was connected for data acquisition. The non-extractable part of the pulp remains retained in the paper after PS-MS analysis. It is important to mention that this part probably contains antioxidant species which, however, could not be detected by the PS-MS approach. The analyses of each individual pulp were done in triplicate for both ionization modes (positive and negative).

For the analyses, the instrumental was operated at: voltage of the PS-MS source equal to $+4.0 \mathrm{kV}$ (positive

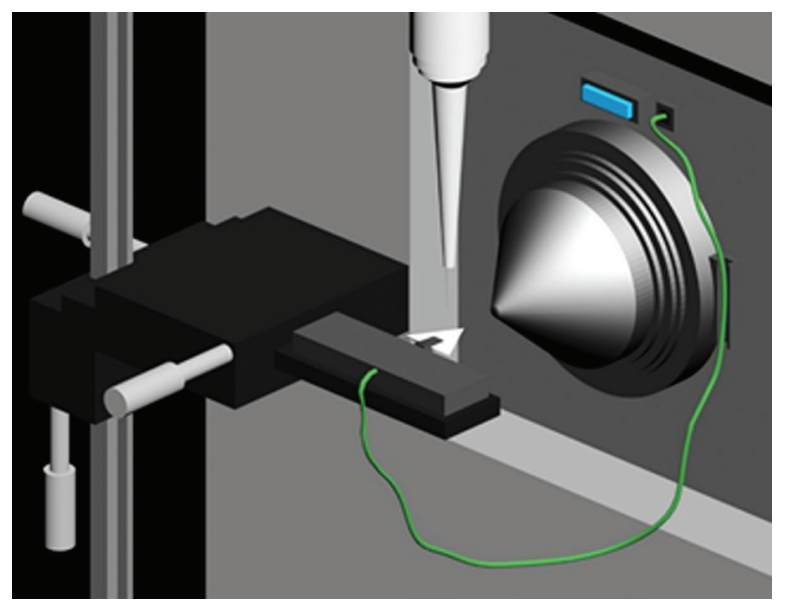

Figure 1. Diagram of ionization source for paper spray. ionization mode) and $-3.0 \mathrm{kV}$ (negative ionization mode); capillary voltage of $40 \mathrm{~V}$; transfer tube temperature of $275^{\circ} \mathrm{C}$; tube lenses voltage of $120 \mathrm{~V}$; and mass range from 50 to $600 \mathrm{~m} / \mathrm{z}$ (positive ionization mode) and from 50 to $1000 \mathrm{~m} / \mathrm{z}$ (negative ionization mode). The ions and their fragments obtained in this analysis were identified based on the data described in literature. Collision energies used to fragmentize the compounds ranged from 15 to $30 \mathrm{eV}$.

\section{Statistical analysis}

Results of physical-chemical analysis and antioxidant activity were subjected to the one-way analysis of variance (ANOVA) and Tukey's test $(p<0.05)$ to evaluate the means. Determination of evaluated factor correlation was executed by Pearson's test $(p<0.05)$, using software Statistica. $^{31}$

The mass spectra obtained were processed with the software Xcalibur. ${ }^{32}$ Mean PS-MS spectra in positive and negative ionization mode for each sample were determined using a spreadsheet of Excel 2013. ${ }^{33}$

Fingerprints of the samples in positive and negative ionization mode were disposed, respectively, in $\mathbf{X}$ $(25 \times 551)$ and $\mathbf{Y}(25 \times 901)$ matrices. Data were centered on the mean, and the principal components analysis were carried out using the software MatLab, ${ }^{34}$ with aid of PLS Toolbox. ${ }^{35}$

To analyze the differentiation capacity of PCA model, a data fusion model was proposed. ${ }^{36}$ This is possible because the detected compounds in both ionization modes were distinct; thus, different information pattern are present in PS(+)-MS and PS(-)-MS results. Therefore, $\mathbf{X}$ and $\mathbf{Y}$ matrices were concentrated to obtain a $\mathbf{Z}(25 \times 1452)$ matrix. Resulting matrix data were treated as the previous ones.

\section{Results and Discussion}

\section{Physical-chemical assay}

In general, cagaitas have high moisture content and low energy content (Table 1). The chemical composition data of cagaitas evaluated in this work corroborates values in other studies on this fruit, including moisture $(91.1 \%),{ }^{37,38}$ protein $(0.63 \%),{ }^{39}$ lipids $(0.20$ to $0.57 \%),{ }^{1,39}$ ashes $(0.18$ to $0.33 \%),{ }^{1,39}$ carbohydrate (5.54 to $\left.8.73 \%\right)^{1,39}$ and energy content (29.83 kcal $\left.100 \mathrm{~g}^{-1}\right) .{ }^{39}$ Moreover, agreement with literature data was observed for the following parameters: soluble solids ( ${ }^{\circ}$ Brix) (8.3 to 9.64$),{ }^{40,41}$ titratable acidity

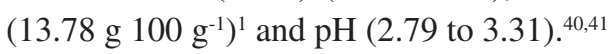


Table 1. Physical-chemical characteristics of cagaitas from Paraopeba, Sete Lagoas and Prudente de Morais

\begin{tabular}{|c|c|c|c|}
\hline \multirow{2}{*}{ Parameter } & \multicolumn{3}{|c|}{ Place of sample collection } \\
\hline & Paraopeba & Sete Lagoas & Prudente de Morais \\
\hline Moisture / \% & $92.06^{\mathrm{a}} \pm 0.40$ & $91.72^{\mathrm{a}} \pm 0.64$ & $92.05^{\mathrm{a}} \pm 0.25$ \\
\hline Protein / (g $\left.100 \mathrm{~g}^{-1}\right)$ & $0.76^{\mathrm{ab}} \pm 0.08$ & $0.71^{\mathrm{b}} \pm 0.09$ & $0.81^{\mathrm{a}} \pm 0.05$ \\
\hline Lipids / (g $\left.100 \mathrm{~g}^{-1}\right)$ & $0.34^{\mathrm{a}} \pm 0.04$ & $0.36^{\mathrm{a}} \pm 0.02$ & $0.27^{\mathrm{b}} \pm 0.01$ \\
\hline Ash / (g $\left.100 \mathrm{~g}^{-1}\right)$ & $0.25^{\mathrm{ab}} \pm 0.04$ & $0.22^{\mathrm{b}} \pm 0.02$ & $0.28^{\mathrm{a}} \pm 0.04$ \\
\hline Carbohydrate / (g $\left.100 \mathrm{~g}^{-1}\right)$ & $6.59^{\mathrm{a}} \pm 1.18$ & $6.99^{\mathrm{a}} \pm 0.58$ & $6.59^{\mathrm{a}} \pm 0.19$ \\
\hline Total energy value / $\left(\mathrm{kcal} 100 \mathrm{~g}^{-1}\right)$ & $35.09^{\mathrm{a}} \pm 0.06$ & $35.37^{\mathrm{a}} \pm 0.34$ & $32.56^{\mathrm{b}} \pm 0.01$ \\
\hline Soluble solids / $\left({ }^{\circ}\right.$ Brix $)$ & $9.56^{\mathrm{a}} \pm 1.02$ & $8.69^{\mathrm{ab}} \pm 0.99$ & $8.23^{b} \pm 0.89$ \\
\hline $\mathrm{pH}$ & $3.18^{\mathrm{a}} \pm 0.15$ & $3.06^{\mathrm{a}} \pm 0.16$ & $3.24^{\mathrm{a}} \pm 0.18$ \\
\hline Titratable acidity / (g citric acid $\left.100 \mathrm{~g}^{-1}\right)$ & $9.66^{\mathrm{a}} \pm 0.22$ & $11.89^{\mathrm{ab}} \pm 0.22$ & $12.69^{\mathrm{b}} \pm 0.22$ \\
\hline
\end{tabular}

Means indicated by the same letters on the same line do not differ at $5 \%$ significance compared to different regions.

\section{Phenolic compounds and antioxidant activity}

Table 2 presents the total phenolic compounds content and antioxidant activity of the sample pool from each microregion. Cagaitas from Paraopeba region exhibited significantly higher amounts of phenolic compounds than those from the other two regions. Phenolic compounds in non-extractable fraction corresponded to between 14.8 and $17.4 \%$ of total content of cagaitas according the region, which demonstrates the importance of evaluating this fraction that is underestimated by other authors (141.95 to $150 \mathrm{mg}$ gallic acid equivalents (GAE) $\left.100 \mathrm{~g}^{-1}\right) .2,37$ Considering other fruits of the Myrtaceae family, cagaitas contained higher values than cambui (Campomanesia phaea Berg.) (246 mg GAE $100 \mathrm{~g}^{-1}$ ), araçá- boi (Eugenia stipitata Mc. Vaugh) (87 mg GAE $100 \mathrm{~g}^{-1}$ ) and araçá (Psidium guineensis Sw.) (129 mg GAE $\left.100 \mathrm{~g}^{-1}\right){ }^{37}$

Considering the total antioxidant activity obtained by DPPH, FRAP and ABTS methods (Table 2), cagaitas from Paraopeba presented statistically higher results than the other regions. The importance must be emphasized in non-extractable fraction determination, as it represented 18.90 to $21.05 \%$ of total antioxidant capacity obtained by FRAP method.

Many studies have reported the significant contribution of phenolic compounds to the antioxidant property of fruits. ${ }^{2,5,38,42}$ The present work corroborates with these data, since a positive correlation with strong intensity $(\mathrm{r}>0.7)$ and significance $(p<0.05)$ between total content

Table 2. Total phenolic compounds and antioxidant activity of cagaitas of Paraopeba, Sete Lagoas and Prudente de Morais

\begin{tabular}{|c|c|c|c|c|}
\hline Parameter & Fraction & $\mathrm{PA}$ & SL & PRU \\
\hline \multirow{4}{*}{ Phenolic compounds / (mg GAE $100 \mathrm{~g}^{-1}$ sample) } & EPP & $367.67^{\mathrm{a}} \pm 17.40$ & $276.31^{\mathrm{b}} \pm 13.62$ & $277.02^{b} \pm 19.59$ \\
\hline & NEPA & $39.90^{\mathrm{a}} \pm 1.82$ & $36.62^{\mathrm{a}} \pm 0.54$ & $37.00^{\mathrm{a}} \pm 1.52$ \\
\hline & HPP & $24.12^{\mathrm{a}} \pm 0.16$ & $18.34^{b} \pm 0.33$ & $21.22^{\mathrm{c}} \pm 0.22$ \\
\hline & total & $431.69^{\mathrm{a}} \pm 15.80$ & $331.27^{\mathrm{b}} \pm 13.26$ & $335.24^{\mathrm{b}} \pm 17.66$ \\
\hline \multirow{4}{*}{ FRAP / ( $\mu$ mol L $L^{-1}$ ferrous sulfate $\mathrm{g}^{-1}$ sample $)$} & EPP & $17.29^{\mathrm{a}} \pm 0.34$ & $12.45^{\mathrm{b}} \pm 0.14$ & $12.83^{\mathrm{b}} \pm 0.32$ \\
\hline & NEPA & $3.61^{\mathrm{a}} \pm 0.35$ & $3.09^{\mathrm{a}} \pm 0.07$ & $2.21^{\mathrm{b}} \pm 0.21$ \\
\hline & HPP & $0.42^{\mathrm{a}} \pm 0.01$ & $0.23^{\mathrm{b}} \pm 0.01$ & $0.33^{\mathrm{c}} \pm 0.01$ \\
\hline & total & $21.33^{\mathrm{a}} \pm 0.39$ & $15.77^{\mathrm{b}} \pm 0.07$ & $15.38^{\mathrm{b}} \pm 0.28$ \\
\hline \multirow{4}{*}{ ABTS / ( $\mu \mathrm{mol} \mathrm{L}^{-1}$ trolox g $\mathrm{g}^{-1}$ sample) } & EPP & $9.34^{\mathrm{a}} \pm 0.34$ & $6.44^{\mathrm{b}} \pm 0.26$ & $6.80^{\mathrm{b}} \pm 0.19$ \\
\hline & NEPA & nd & nd & nd \\
\hline & HPP & nd & nd & nd \\
\hline & total & $9.34^{\mathrm{a}} \pm 0.34$ & $6.44^{\mathrm{b}} \pm 0.26$ & $6.80^{\mathrm{b}} \pm 0.19$ \\
\hline DPPH / ( $\mu \mathrm{mol} \mathrm{L}^{-1} \mathrm{TE} \mathrm{g}^{-1}$ sample $)$ & total & $11.47^{\mathrm{a}} \pm 0.87$ & $7.09^{\mathrm{b}} \pm 0.47$ & $7.64^{\mathrm{b}} \pm 0.50$ \\
\hline
\end{tabular}

PA: Paraopeba; SL: Sete Lagoas; PRU: Prudente de Morais; GAE: gallic acid equivalents; FRAP: ferric reducing antioxidant power; ABTS: 2,20-azinobis(3-ethylbenzthiazoline-6-sulfonic acid); DPPH: 2,2-diphenyl-1-picrylhydrazil; EPP: extractable polyphenols; NEPA: non-extractable proanthocyanidins; HPP: hydrolysable polyphenols; nd: not detected. Means indicated by equal letters on the same line do not differ at $5 \%$ significance in the comparison with different regions. 
of phenolic compounds and total antioxidant activity was observed for ABTS $(r=0.910)$, FRAP $(r=0.937)$ and DPPH $(r=0.999)$ methods; and between FRAP and ABTS $(r=0.963)$, FRAP and DPPH $(r=0.985)$, and ABTS and DPPH $(r=1.00)$.

\section{PS-MS fingerprints}

Examples of PS-MS spectra of cagaitas in positive and negative ionization modes are illustrated in Figure 2. The proposed molecules from the obtained ions in the negative and positive ionization modes were amino acids, sugars, delphinidins, coumarins, organic acids, sugars and phenolic compounds.

\section{PS(+)-MS fingerprints}

Table 3 shows the possible compounds detected in the fingerprints (positive ionization mode) of cagaitas. The analysis with the positive ionization mode were performed
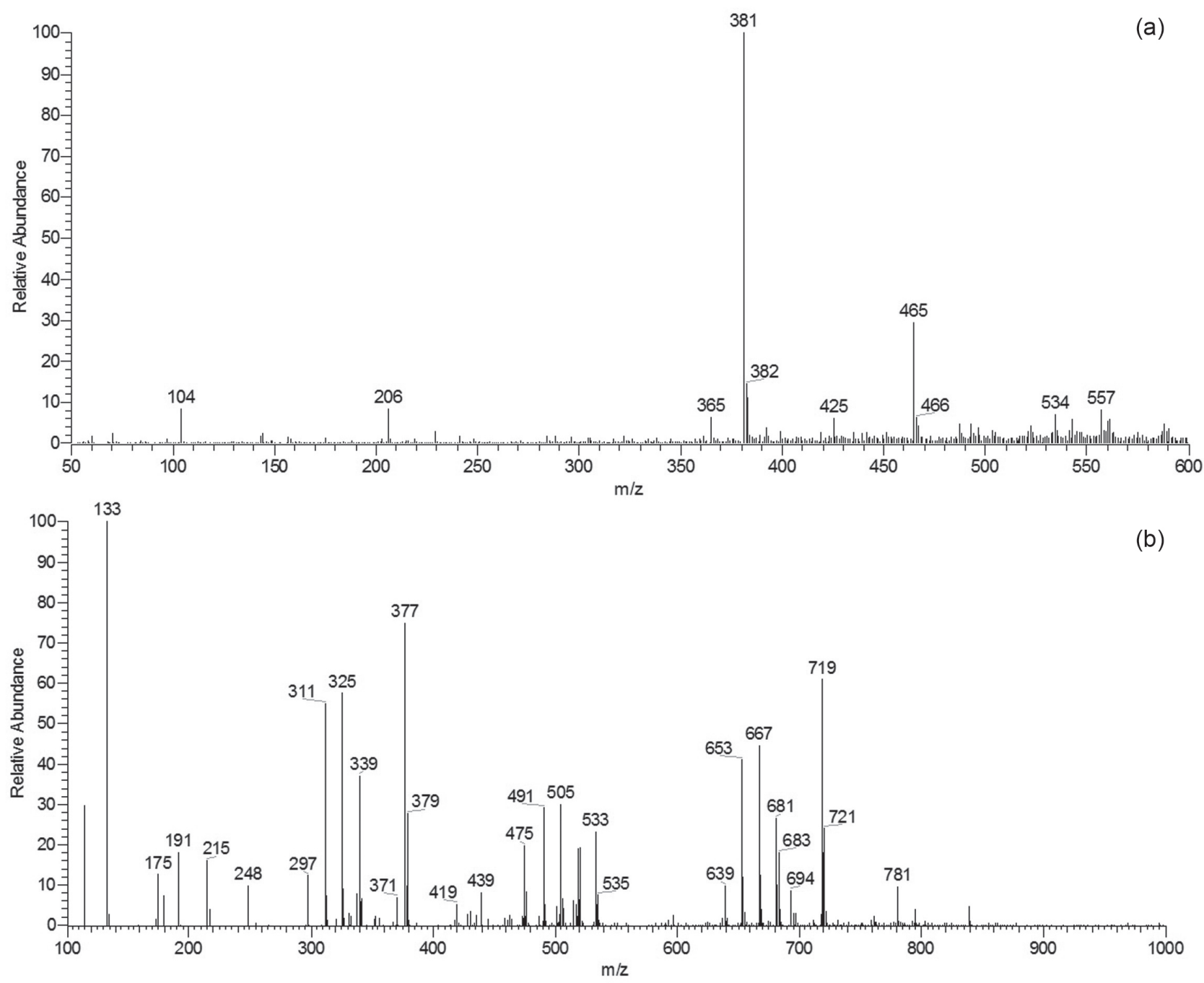

Figure 2. Representation of (a) PS(+)-MS and (b) PS(-)-MS of a cagaita sample.

Table 3. Compounds identified in cagaitas by PS(+)-MS

\begin{tabular}{lcccc}
\hline Tentatively identification & $m / z$ & ID & MS/MS & Reference \\
\hline L-Arginine & 175 & {$[\mathrm{M}+\mathrm{H}]^{+}$} & 70,129 & Gogichaeva et al. ${ }^{43}$ Ozcan and Senyuva ${ }^{44}$ \\
Citropten & 206 & {$[\mathrm{M}]^{+}$} & 121 & ${\text { Ledesma-Escobar } \text { et al. }{ }^{45}}$ \\
Sucrose & 381 & {$\left[2 \mathrm{Hex}+\mathrm{K}-\mathrm{H}_{2} \mathrm{O}\right]^{+}$} & 201,219 & Yuan et al. , $^{46}$ Asakawa and Hiraoka ${ }^{47}$ \\
Delphinidin-3-glucoside & 465 & {$[\mathrm{M}]^{+}$} & 303 & Flores et al. ${ }^{48}$ Silva et al. ${ }^{49}$ \\
\hline
\end{tabular}


specifying the ratio mass charge from 50 up to 600 , since in previous assays we observed the sample has not presented any ion above this range.

The signal $\mathrm{m} / \mathrm{z} 175$ probably refers to protonated L-arginine. This amino acid had a different fragmentation pattern than commonly observed in other amino acids, not being characterized by the loss of $\mathrm{NH}_{3}$. Its classification was confirmed by distinguishing ions obtained after the fragmentation reactions $(\mathrm{m} / \mathrm{z}, 70$ and 129).

The signal with $m / z 381$ was proposed as being sucrose $\left[2 \mathrm{Hex}+\mathrm{K}-\mathrm{H}_{2} \mathrm{O}\right]^{+}$. Such characterization was performed in works by Asakawa and Hiraoka ${ }^{47}$ as well as Chen et al. ${ }^{50}$ when they investigated the presence of oligosaccharides in fruits using mass spectrometry. The existence of this sugar in pulp of unpeeled cagaitas has already been related by Ribeiro et al., ${ }^{1}$ when they found $0.59 \%$ of sucrose.

The ion with $\mathrm{m} / \mathrm{z} 206$ can be recognized as citropten, based on its transition MS/MS $206 \rightarrow 121$, which was also observed by Ledesma-Escobar et al. ${ }^{45}$ when evaluating the identification parameters of coumarins in lemon (Citrus limon) by liquid chromatography mass spectrometry (LC-MS). The ion with $m / z 465$ was assigned as delphinidin-3-glucoside, and the confirmation was based on its ion $\mathrm{MS}^{2}(\mathrm{~m} / \mathrm{z}, 303,-162 \mathrm{amu})$, resulting from the loss of a hexose unit. Previous studies with cagaitas evaluated only total anthocyanins as reported by Siqueira et al.,${ }^{51}$ who

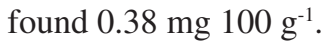

\section{PS(-)-MS fingerprints}

Fingerprints of cagaitas obtained using PS-MS in negative ionization mode are in Table 4. This method helped identify several compounds including organic acids, sugars and phenolic compounds.

\section{Organic acids}

The signals with $\mathrm{m} / \mathrm{z}, 115$ and 133 showed fragmented ions with $\mathrm{m} / 2.71\left[\mathrm{C}_{3} \mathrm{H}_{3} \mathrm{O}_{2}\right]$ and $89\left[\mathrm{M}-\mathrm{H}-\mathrm{CO}_{2}\right]^{-}$; thus, they were proposed as malic acid. Ion with $\mathrm{m} / z$ 191 was recognized as citric acid based on obtained ions after the fragmentation reaction with $\mathrm{m} / \mathrm{z} 85$ and 111 $\left[\mathrm{M}-\mathrm{H}_{2} \mathrm{O}-\mathrm{COOH}-\mathrm{OH}\right]^{-}$. Ramos et al..$^{52}$ also found these two organic acids when investigating contents of araçá-pera (Psidium acutangulum) by HPLC-MS.

\section{Sugars}

Based on the fragmentation profile shown in Table 4, signals with $m / z 179,215,377$ and 521 were recognized as sugars. Ribeiro et al. ${ }^{1}$ found by HPLC the presence of

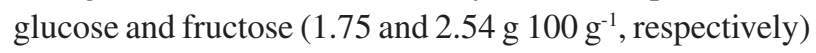
in pulp of unpeeled cagaitas. Results obtained in this present study agree with Chen et al.,${ }^{50}$ who determined the oligosaccharides present in fruits through electrospray droplet impact/secondary ion mass spectrometry (EDI/SIMS), and Roesler et al. ${ }^{53}$ who investigated the main contents of araticum (Annona crassiflora) by ESI-MS.

\section{Hydroxycinnamic acids}

The signal with $m / z 311$ showed fragmentation ion with $\mathrm{m} / \mathrm{z}, 133$, recognized as caftaric acid, which corresponds to a non-flavonoid phenolic compound originating

Table 4. Ions identified in cagaitas by PS(-)-MS

\begin{tabular}{|c|c|c|c|c|}
\hline Tentatively identification & $m / z$ & ID & MS/MS & Reference \\
\hline Malic acid & 115 & {$\left[\mathrm{M}-\mathrm{H}_{2} \mathrm{O}-\mathrm{H}^{-}\right.$} & 71 & Wang et al..$^{54}$ \\
\hline Malic acid & 133 & {$[\mathrm{M}-\mathrm{H}]^{-}$} & 89,115 & Roesler et al. ${ }^{53}$ \\
\hline Hexose & 179 & {$[\mathrm{M}-\mathrm{H}]^{-}$} & 71,89 & Roesler et al. ${ }^{53}$ Wang et al. ${ }^{54}$ \\
\hline Citric acid & 191 & {$[\mathrm{M}-\mathrm{H}]^{-}$} & 85,111 & Wang et al. ${ }^{54}$ \\
\hline Hexose & 215 & {$\left[\mathrm{Hex}+2 \mathrm{H}_{2} \mathrm{O}-\mathrm{H}\right]^{-}$} & $71,89,179$ & Guo et al. ${ }^{8}$ Wang et al. ${ }^{54}$ \\
\hline Caftaric acid & 311 & {$[\mathrm{M}-\mathrm{H}]^{-}$} & 133 & Abu-Reidah et al. ${ }^{55}$ \\
\hline$p$-Coumaric acid hexoside & 325 & {$[\mathrm{M}-\mathrm{H}]^{-}$} & 119,145 & Aaby et al.,$^{56}$ Kajdžanoska et al. ${ }^{57}$ \\
\hline Cafeoil- $D$-glucose & 339 & {$[\mathrm{M}-\mathrm{H}]^{-}$} & 159 & - \\
\hline Syringic acid hexoside & 359 & {$[\mathrm{M}-\mathrm{H}]^{-}$} & 153,197 & Abu-Reidah et al. ${ }^{55}$ Barros et al. ${ }^{58}$ \\
\hline Hexose or sucrose & 377 & $\begin{array}{c}{\left[2 \mathrm{Hex}+\mathrm{H}_{2} \mathrm{O}-\mathrm{H}\right]^{-} \text {or }} \\
{\left[\mathrm{Suc}+2 \mathrm{H}_{2} \mathrm{O}-\mathrm{H}\right]^{-}}\end{array}$ & 341 & Chen et al..$^{50}$ \\
\hline Vitexin & 431 & {$[\mathrm{M}-\mathrm{H}]^{-}$} & 341 & Wang et al.,$^{48}$ Koolen et al. ${ }^{59}$ \\
\hline Dimethylellagic acid hexoside & 491 & {$[\mathrm{M}-\mathrm{H}]^{-}$} & 454 & Gordon et al. ${ }^{60}$ \\
\hline Hexose & 521 & {$\left[3 \mathrm{Hex}-\mathrm{H}_{2} \mathrm{O}-\mathrm{H}\right]^{-}$} & 341 & - \\
\hline Galloylated caffeic acid hexoside & 681 & {$[\mathrm{M}-\mathrm{H}]^{-}$} & 511 & - \\
\hline Caffeic acid hexoside dimer & 683 & {$[\mathrm{M}-\mathrm{H}]^{-}$} & 341 & Spínola et al. ${ }^{61}$ \\
\hline
\end{tabular}


from the esterification of caffeic acid with tartaric acid. Previous studies have already reported its presence in a Chinese medical plant (Taraxacum formosanum) and in wines. ${ }^{62,63}$

The ion with $\mathrm{m} / \mathrm{z} 325$ probably corresponded to a hydroxycinnamic acid conjugated to a hexose called $p$-coumaric acid hexoside. Classification was proposed by mass spectra $\mathrm{MS}^{2}$ with $\mathrm{m} / z 119$ and 145 . This substance was reported previously by Kajdžanoska et al..$^{57}$ in strawberries and by Mikulic-Petkovsek et al. ${ }^{64}$ in blueberries (Vaccinium myrtillus L.) through liquid chromatography coupled to diode array detection and electrospray ionization tandem mass spectrometry (LC/DAD/ESI-MS).

The signal with $m / z 339$ was assigned to caffeic acid in the conjugated form with a hexose (cafeoil- $D$-glucose). The obtained fragmented ion $(\mathrm{m} / \mathrm{z}, 159)$ resulted from the loss of caffeic acid $(-170 \mathrm{amu})$. Caffeic acid has already been described in cagaitas by Guedes et al. ${ }^{65}$ employing HPLC. This substance in this conjugated form was reported by Chen et al. ${ }^{63}$ in Chinese medical herbs through LC-MS/MS.

The ion with $\mathrm{m} / \mathrm{z} 681$ may be defined as galloylated caffeic acid hexoside, since it presented characteristic fragmentation profile from the loss of gallic acid (ion $\mathrm{m} / \mathrm{z} 511,-170 \mathrm{amu})$. The substance with $\mathrm{m} / \mathrm{z} 683$ may be recognized as caffeic acid hexoside dimer, as it had transition MS/MS 683 $\rightarrow 341$, probably resulting from loss of hexose (-342 amu).

\section{Hydroxybenzoic acids}

The signal with $m / z 359$ may be recognized as syringic acid hexoside, because it presented fragmented ions with $\mathrm{m} / \mathrm{z} 153\left(\left[\mathrm{M}-\mathrm{H}-\mathrm{CO}_{2}\right]\right)$ and 197, which resulted from elimination of a hexosyl group (-162 amu). Guedes et al. ${ }^{65}$ already described syringic acid in cagaitas. The signal with $\mathrm{m} / \mathrm{z} 491$ presented a fragmented ion with $\mathrm{m} / \mathrm{z} 454$, identified as dimethylellagic acid hexoside.

\section{Flavones}

A substance with $\mathrm{m} / \mathrm{z}, 431$ with fragmentation profile with $\mathrm{m} / \mathrm{z} 341\left(\left[\mathrm{C}_{18} \mathrm{H}_{13} \mathrm{O}_{7}\right]^{-}\right)$was recognized as vitexin. This flavone, belonging to the flavonoids class, has already been reported by Silva et al. ${ }^{49}$ in jussara fruit (Euterpe edulis Mart.), using HPLC-DAD-MS/MS. Koolen et al. ${ }^{59}$ also identified this flavonoid when investigating phenolic compounds of buriti (Mauritia flexuosa L. f.) by UPLC-ESI-MS/MS.

\section{Principal components analysis}

Principal components analysis was executed for data matrices $\mathbf{X}(25 \times 551)$ and $\mathbf{Y}(25 \times 901)$ made from PS(+)-MS and PS(-)-MS spectra. Results of these models showed the differentiation of some samples, mainly due to compounds L-arginine, sucrose, delphinidin3 -glucoside, and citropten in positive ionization mode and to the substances citric acid, caftaric acid, $p$-coumaric acid hexoside, hexoses and dimethylellagic acid hexoside in negative ionization mode. Both models were constructed by selecting 3 principal components, which explained, respectively, $92.23 \%$ (positive ionization mode) and $70.79 \%$ (negative ionization mode) of total data variability.

As the information patterns obtained by both ionization methods were different, classification models were also constructed from the approach of data fusion. Thus, distinct information could be correlated from this data set to enhance the classification capacity of this model.

Data fusion was carried out from the simple concatenation of the data matrices $\mathbf{X}$ and $\mathbf{Y}$, what resulted in a $\mathbf{Z}$ matrix $(25 \times 1452)$. Resulting PCA model consisted in selection of three principal variables, which explain a total of $65.32 \%$ of total data variability.

Figure 3 illustrates the scores of PC 1, PC 2 and PC 3 of the PCA model after data fusion.

The principal component 1 (33.26\% of data variability) allowed most of the samples from the microregions Prudente de Morais and Paraopeba (positive scores) to be separated from Sete Lagoas samples (negative scores). Loading analysis of PC 1 shows that samples with positive values presented ions with $\mathrm{m} / \mathrm{z} 381$ (positive ionization mode) and $m / z$ 179, 191 215, 311, 325, 340, 371, 491, 505 and 519 (negative ionization mode). Samples with negative score values presented the variables $\mathrm{m} / \mathrm{z} 377,431,521,683$ and 719 (negative ionization mode) and $m / z 206,392$ and 465 (positive ionization mode) with higher loading values.

This indicates that factors that may differentiate samples from these regions differ mainly in the kind of phenolic substance that come from the conditions of metabolic stress and genetic variability. This hypothesis is plausible, since some samples from Paraopeba (PA 1, 7, 8 and 9) are grouped together to the Sete Lagoas samples.

Principal component 2 (17.44\% of the variability) differentiated some of the samples from Prudente de Morais (PRU 6 and PRU 7) in relation to the other samples. Loadings analysis of this component indicates that sample PRU 6 and PRU 7 presented signal with $m / z$ 133, 191, 333 and 339 (negative ionization mode) and $m / z .70,104,143$, 175, 206, 392 and 465 (positive ionization mode). 

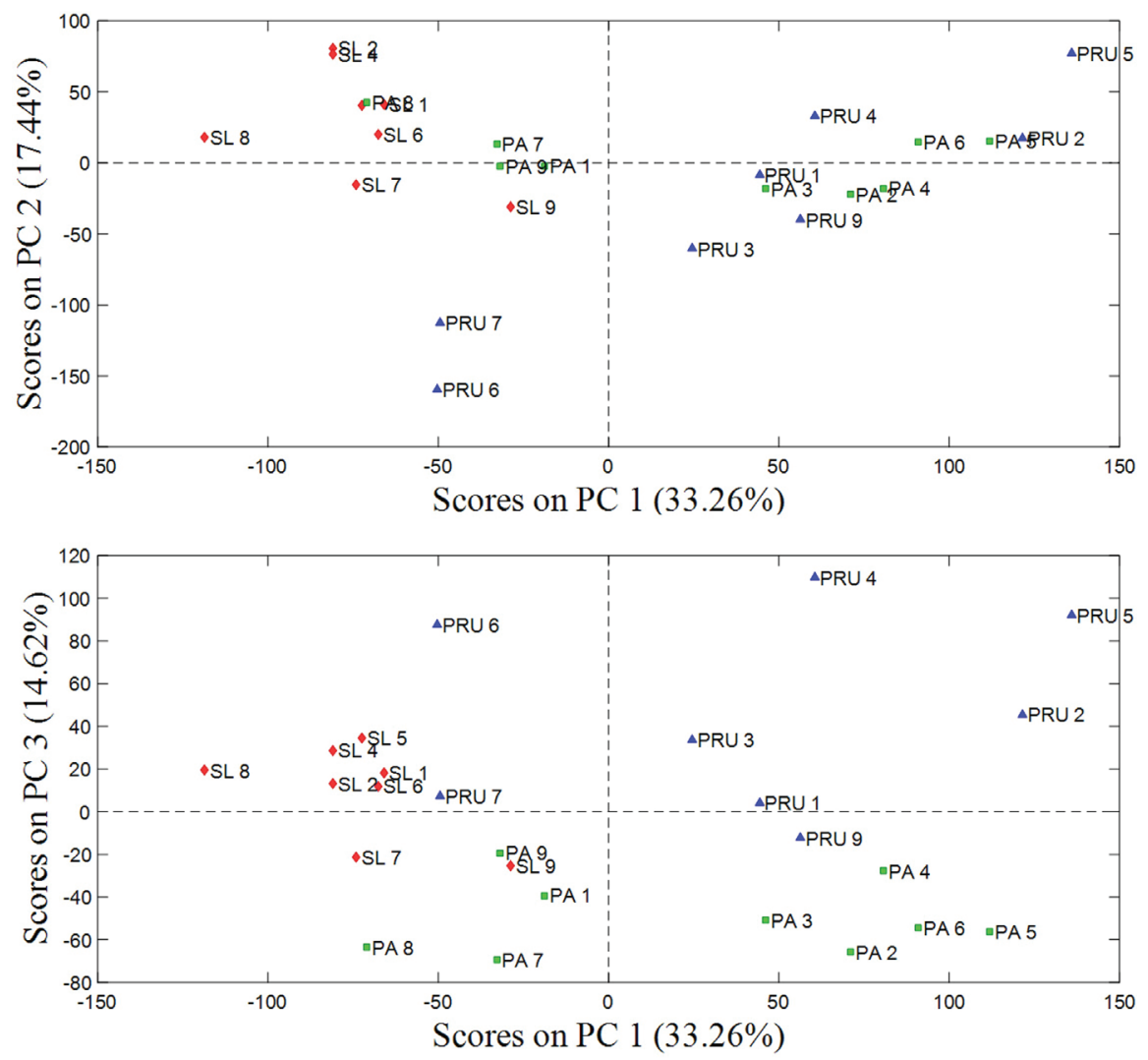

Figure 3. PC 1, PC 2 and PC 3 scores. PA: Paraopeba, SL: Sete Lagoas, PRU: Prudente de Morais.

As for the principal component 3 (14.62\% of the variability), it allowed the discrimination of cagaitas from Paraopeba (negative scores). Loadings analysis of this PC showed that the differentiation of these samples occurred mainly due to signals with $\mathrm{m} / z .133,175,191,371,431$ and 521 (negative ionization mode) and $\mathrm{m} / \mathrm{z} 381$ (positive ionization mode).

Figure 4 shows the loadings of variables of PC 1 (Figure 4a), PC 2 (Figure 4b) and PC 3 (Figure 4c) after data fusion. Signals of some sugars with $\mathrm{m} / \mathrm{z} 377$ $\left(\left[2 \mathrm{Hex}+\mathrm{H}_{2} \mathrm{O}-\mathrm{H}\right]^{-}\right.$or $\left.\left[\mathrm{Suc}+2 \mathrm{H}_{2} \mathrm{O}-\mathrm{H}\right]^{-}\right)$and the signal with $m / z 719$ contributed with stronger negative signals for the formation of grouping 1 and 2 in PC 1. On the other hand, grouping 3 was a function of the positive signal from potassium adduct of sucrose $\left(\left[2 \mathrm{Hex}+\mathrm{K}-\mathrm{H}_{2} \mathrm{O}\right]^{+}\right.$, $\mathrm{m} / \mathrm{z}, 381)$ and from the signals of hexose $(\mathrm{m} / \mathrm{z}, 179)$, citric acid $(\mathrm{m} / \mathrm{z} 191)$, hexose $(\mathrm{m} / \mathrm{z} 215)$, caftaric acid $(\mathrm{m} / \mathrm{z} 311)$, $p$-coumaric acid hexoside $(\mathrm{m} / \mathrm{z}, 325)$ and dimethylellagic acid hexoside $(\mathrm{m} / \mathrm{z} 491)$.

The variations in cagaita composition may be associated with some factors like geographic location of the fruit, genetic variability, stress factors, sun exposure and temperature. ${ }^{1}$

Therefore, PS-MS method may be a more adequate analysis tool to determine content of phenolic substances, because it permits fast, simple and low-cost analysis of each individual fruit.

\section{Conclusions}

Cagaitas contained high levels of phenolic compounds and intermediate values of antioxidant activity found with the three assessed methods (ABTS, FRAP and DPPH), and these values were higher for fruit from Paraopeba when compared with other regions. Compounds in the non-extractable fraction such as pro-anthocyanidin and hydrolysable polyphenols contained 14.8 to $17.4 \%$ of phenolic compounds and 16 to $21 \%$ of antioxidant activity in relation to the total. The levels of total phenolic compounds showed good positive correlation with the three methods used to evaluate the antioxidant activity. PS-MS was demonstrated to be a simple and fast technique to obtain the fingerprint of cagaita content, identifying several compounds such as organic acids, sugars, amino acids and phenolic compounds.

\section{Supplementary Information}

Supplementary information is available free of charge at http://jbcs.sbq.org.br as PDF file. 

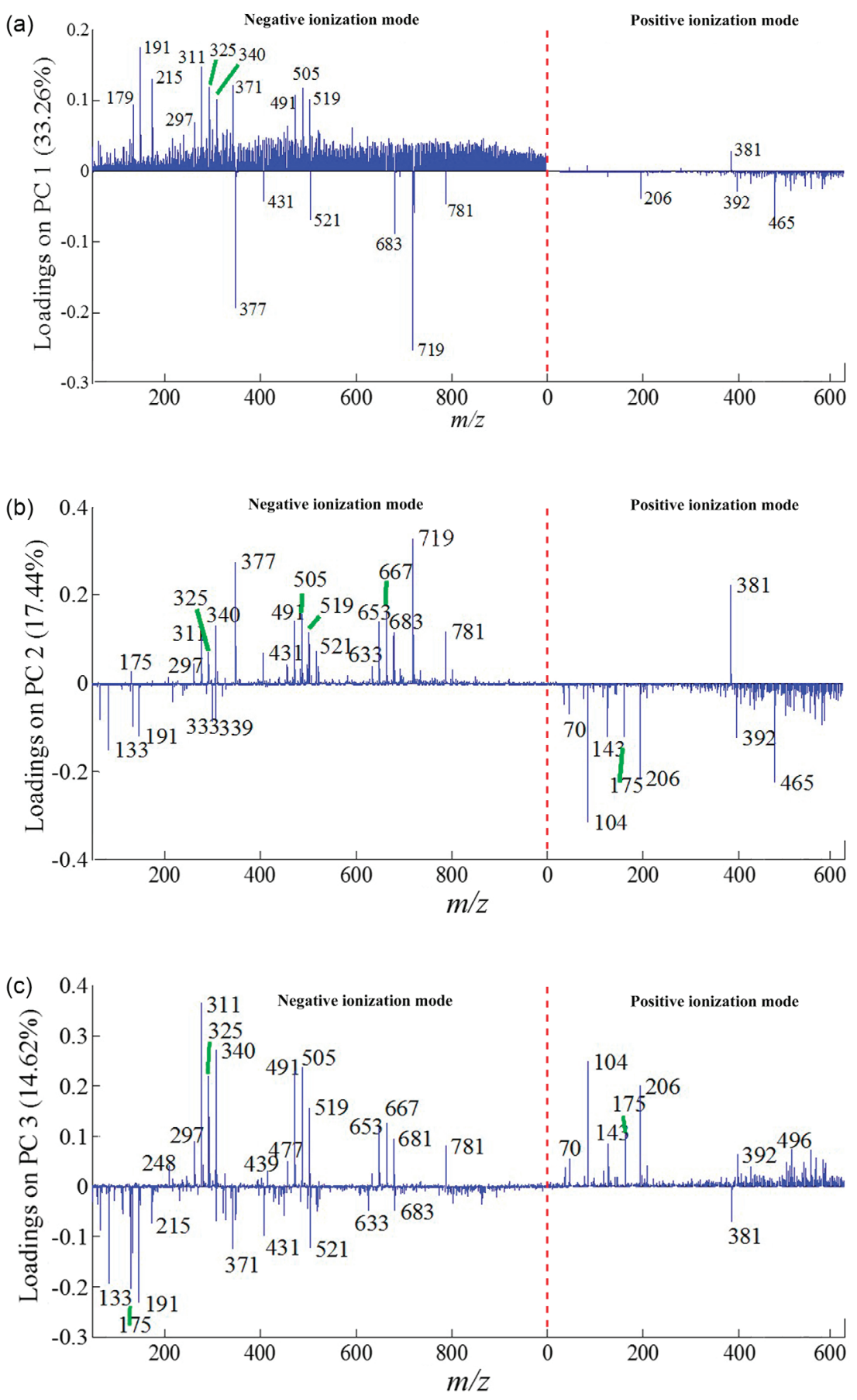

Figure 4. Representation of the loadings responsible for the discrimination of the samples scores in (a) PC 1; (b) PC 2 and (c) PC 3.

\section{Acknowledgments}

The authors thank CNPq, CAPES and FAPEMIG for financial support.

\section{References}

1. Ribeiro, E. M. G.; Carvalho, L. M. J.; Ortiz, G. M. D.; Cardoso, F. S. N.; Viana, D. S.; Carvalho, J. L. V.; Gomes, P. B.; Tebaldi,
N. M. In Food Industry; Muzzalupo, I., ed; Viktorija Zgela: Rijeka, Croatia, 2013, ch. 1.

2. Alves, A. M.; Dias, T.; Hassimotto, N. M. A.; Naves, M. M. V.; Food Sci. Technol. 2017, 37, 564.

3. Duarte, A. R.; Naves, R. R.; Santos, S. C.; Seraphin, J. C.; Ferri, P. H.; J. Braz. Chem. Soc. 2010, 21, 1459.

4. Vilela, E. C.; Carvalho, T. C.; Duarte, A. R.; Naves, R. R.; Santos, S. C.; Seraphin, J. C.; Ferri, P. H.; J. Braz. Chem. Soc. 2012, 23, 1776. 
5. Rufino, M. S. M.; Alves, R. E.; Brito, E. S.; Pérez-Jiménez, J.; Saura-Calixto, F.; Mancini-Filho, J.; Food Chem. 2010, 121, 996.

6. Pérez-Jiménez, J.; Días-Rubio, M. E.; Saura-Calixto, F.; Nutr. Res. Rev. 2013, 26, 118.

7. Zhi-Ping, Z.; Xiao-Ning, L.; Ya-Jun, Z.; Chin. J. Anal. Chem. 2014, 42, 145.

8. Guo, Y.; Gu, Z.; Liu, X.; Liu, J.; Ma, M.; Chen, B.; Wang, L.; Phytochem. Anal. 2017, 28, 344.

9. Wang, H.; Liu, J.; Cooks, R. G.; Ouyang, Z.; Angew. Chem., Int. Ed. 2010, 122, 889.

10. Donna, L. D.; Taverna, D.; Indelicato, S.; Napoli, A.; Sindona, G.; Mazzotti, F.; Food Chem. 2017, 229, 354.

11. Mazzotti, F.; Donna, L. D.; Taverna, D.; Nardi, M.; Aiello, D.; Napoli, A.; Sindona, G.; Int. J. Mass Spectrom. 2013, 352, 87.

12. Pereira, H. V.; Amador, V. S.; Sena, M. M.; Augusti, R.; Piccin, E.; Anal. Chim. Acta 2016, 940, 104.

13. Teodoro, J. A. R.; Pereira, H. V.; Sena, M. M.; Piccin, E.; Zacca, J. J.; Augusti, R.; Food Chem. 2017, 237, 1058.

14. Garrett, R.; Rezende, C. M.; Ifa, D. R.; Anal. Methods 2013, 5 , 5944.

15. Taverna, D.; Donna, L. D.; Bartella, L.; Napoli, A.; Sindona, G.; Mazzotti, F.; Anal. Bioanal. Chem. 2016, 408, 3783.

16. Sneha, M.; Dulay, M. T.; Zare, R. N.; Int. J. Mass Spectrom. 2017, 418, 156.

17. Evard, H.; Kruve, A.; Lõhmus, R.; Leito, I.; J. Food Compos. Anal. 2015, 41, 221.

18. Deng, J.; Yang, Y.; Anal. Chim. Acta 2013, 785, 82.

19. Taverna, D.; Donna, L. D.; Mazzotti, F.; Policicchio, B.; Sindona, G.; J. Mass Spectrom. 2013, 48, 544.

20. Li, A.; Wei, P.; Hsu, H.-C.; Cooks, R. G.; Analyst 2013, 138, 4624.

21. Alberici, R. M.; Simas, R. C.; Sanvido, G. B.; Romão, W.; Lalli, P. M.; Benassi, M.; Cunha, I. B. S.; Eberlin, M. N.; Anal. Bioanal. Chem. 2010, 398, 265.

22. Ifa, D. R.; Wu, C.; Ouyang, Z.; Cooks, R. G.; Analyst 2010, 135,669 .

23. Weston, D. J.; Analyst 2010, 135, 661.

24. Mandal, M. K.; Ozawa, T.; Saha, S.; Rahman, M. M.; Iwasa, M.; Shida, Y.; Nonami, H.; Hiraoka, K.; J. Agric. Food Chem. 2013, 61, 7889.

25. Association of Official Analytical Chemistry (AOAC); Official Methods of Analysis, $19^{\text {th }}$ ed.; AOAC: Gaithersburg, Maryland, USA, 2018.

26. Bligh, E. G.; Dyer, W. J.; Can. J. Biochem. Physiol. 1959, 37, 911.

27. Merril, A. L.; Watt, B. K.; Energy Value of Foods: Basis and Derivation; United States Department of Agriculture: Washington, USA, 1973.

28. Hartzfeld, P. W.; Forkner, R.; Hunter, M. D.; Hagerman, A. E.; J. Agric. Food Chem. 2002, 50, 1785.
29. Arranz, S.; Saura-Calixto, F.; Shaha, S.; Kroon, P. A.; J. Agric. Food Chem. 2009, 57, 7298.

30. Singleton, V. L.; Orthofer, R.; Lamuela-Raventós, R. M.; Methods Enzymol. 1999, 299, 152.

31. Statistica, version 10.0; StataSoft: Tulsa, OK, USA, 2011.

32. Xcalibur, version 2.1; Thermo Scientific: San Jose, CA, USA, 2011.

33. Excel 2013; Microsoft: Redmond, WA, USA, 2013.

34. MatLab, version 7.9.0.529; Mathworks: Natick, MA, USA, 2009.

35. PLS Toolbox, version 5.2.2; Eigenvectors Research: Manson, WA, USA, 2009.

36. Gutiérrez, J. M.; Haddi, Z.; Amari, A.; Bouchikhi, B.; Mimendia, A.; Cetó, X.; Valle, M. D.; Sens. Actuators, B 2013, 177, 989.

37. Genovese, M. I.; Pinto, M. S.; Gonçalves, A. E. S. S.; Lajolo, F. M.; Food Sci. Technol. Int. 2008, 14, 207.

38. Gonçalves, A. E. S. C.; Lajolo, F. M.; Genovese, M. I.; J. Agric. Food Chem. 2010, 58, 4666.

39. Cardoso, L. M.; Martino, H. S. D.; Moreira, A. V. B.; Ribeiro, S. M. R.; Pinheiro-Sant'ana, H. M.; Food Res. Int. 2011, 44, 2151.

40. Oliveira, M. E. S.; Pantoja, L.; Duarte, W. F.; Collela, C. F.; Valarelli, L. T.; Schwan, R. F.; Dias, D. R.; Food Res. Int. 2011, 44, 2391.

41. Bueno, G. H.; Guedes, M. N. S.; Souza, A. G.; Madeira, A. P. C.; Garcia, E. M.; Taroco, H. A.; Melo, J. O. F.; Rev. Bras. Biometria 2017, 35, 515.

42. Pereira, M. C.; Steffens, R. S.; Jablonski, A.; Hertz, P. F.; Rios, A. O.; Vizzotto, M.; Flores, S. H.; J. Agric. Food Chem. 2012, 60, 3061 .

43. Gogichaeva, N. V.; Williams, T.; Alterman, M. A.; J. Am. Soc. Mass Spectrom. 2007, 18, 279.

44. Ozcan, S.; Senyuva, H. Z.; J. Chromatogr. A 2006, 1135, 179.

45. Ledesma-Escobar, C. A.; Priego-Capote, F.; Castro, M. D. L.; Eur. J. Mass Spectrom. 2015, 50, 1196.

46. Yuan, H.; Wu, Y.; Liu, W.; Liu, Y.; Gao, X.; Lin, J.; Zhao, Y.; Carbohydr. Res. 2015, 407, 5.

47. Asakawa, D.; Hiraoka, K.; Rapid Commun. Mass Spectrom. 2010, 24, 2431.

48. Flores, G.; Dastmalchi, K.; Paulino, S.; Whalen, K.; Dabo, A. J.; Reynertson, K. A.; Foronjy, R. F.; D'armiento, J. M.; Kennelly, E. J.; Food Chem. 2012, 134, 1256.

49. Silva, N. A.; Rodrigues, E.; Mercadante, A. Z.; Rosso, V. V.; J. Agric. Food Chem. 2014, 62, 5072.

50. Chen, R.; Wang, L.; Xiong, C.; Zhou, Y.; Zhen, C.; Zhang, N.; Tang, Y.; Zhou, X.; Wang, J.; Nie, Z.; Chen, Y.; Analyst 2011, 136, 3809.

51. Siqueira, E. M. A.; Rosa, F. R.; Fustinoni, A. M.; Sant'ana, L. P.; Arruda, S. F.; PLoS One 2013, 8, e72826. 
52. Ramos, A. S.; Souza, R. O. S.; Boleti, A. P. A.; Bruginski, E. R. D.; Lima, E. S.; Campos, F. R.; Machado, M. B.; Food Res. Int. 2015, 75, 315.

53. Roesler, R.; Catharino, R. R.; Malta, L. G.; Eberlin, M. N.; Pastore, G.; Food Chem. 2007, 104, 1048.

54. Wang, J.; Jia, Z.; Zhang, Z.; Wang, Y.; Liu, X.; Wang, L.; Lin, R.; Molecules 2017, 22, DOI: 10.3390/molecules22030476.

55. Abu-Reidah, I. M.; Ali-Shtayeh, M. S.; Jamous, R. M.; ArráezRomán, D.; Segura-Carretero, A.; Food Chem. 2015, 166, 179.

56. Aaby, K.; Ekeberg, D.; Skrede, G.; J. Agric. Food Chem. 2007, $55,4395$.

57. Kajdžanoska, M.; Gjamovski, V.; Stefova, M.; Maced. J. Chem. Chem. Eng. 2010, 29, 181.

58. Barros, L.; Dueñas, M.; Carvalho, A. M.; Ferreira, I. C. F. R.; Santos-Buelga, C.; Food Chem. Toxicol. 2012, 50, 1576.

59. Koolen, H. H. F.; Silva, F. M. A.; Gozzo, F. C.; Souza, A. Q. L.; Souza, A. D. L.; Food Res. Int. 2013, 51, 467.
60. Gordon, A.; Jungfer, E.; Silva, B. A.; Maia, J. G. S.; Marx, F.; J. Agric. Food Chem. 2011, 59, 7688.

61. Spínola, V.; Pinto, J.; Castilho, P. C.; Food Chem. 2015, 173, 14.

62. Sun, J.; Liang, F.; Bin, Y.; Li, P.; Duan, C.; Molecules 2007, 12, 679.

63. Chen, H.-J.; Inbaraj, B. S.; Chen, B.-H.; Int. J. Mol. Sci. 2012, $13,260$.

64. Mikulic-Petkovsek, M.; Schmitzer, V.; Slatnar, A.; Stampar, F.; Veberic, R.; J. Sci. Food Agric. 2015, 95, 776.

65. Guedes, M. N. S.; Rufini, J. C. M.; Marques, T. R.; Melo, J. O. F.; Ramos, M. C. P.; Viol, R. E.; Rev. Bras. Frutic. 2017, 39, 1.

Submitted: September 4, 2018 Published online: January 8, 2019 